\title{
New and poorly known Acrolepiinae from the Palaearctic, Afrotropical, Neotropical and Oriental regions (Lepidoptera: Glyphipterigidae)
}

\author{
With 23 figures
}

ReINHARD GAEDIKE ${ }^{1,2}$

${ }^{1}$ Florusstraße 5, 53225 Bonn, Germany. - tinagma@msn.com
${ }^{2}$ Senckenberg Deutsches Entomologisches Institut, Eberswalder Straße 90, 15374 Müncheberg, Germany
Published on 2016-12-20

\section{Summary}

Six new species are described: Digitivalva kenyacola, Acrolepiopsis falcata, Acrolepiopsis lativalvata, Acrolepiopsis juratae, Acrolepiopsis fibigeri, Acrolepia peruana. The female genitalia of Acrolepiopsis jaspidata (Meyrick, 1919) are described for the first time. New country records are established for four species: Acrolepia dioscoreivora GiBEAUx, 1989, Acrolepiopsis nagaimo YASUdA, 2000, Acrolepiopsis brevipenella MorIUTI, 1972, Acrolepiopsis persimilis MorIUTI, 1974. The first specimens of Acrolepiopsis halosticta (MEYRICK, 1914) apart from the type series were found. Acrolepiopsis persimilis Moriuti, 1974, hitherto regarded as a synonym of Acrolepiopsis suzukiella (MATsumurA, 1931), is re-established as a valid species.

\section{Key words}

Palaearctic, Afrotropical region, Neotropical region, Oriental region, Lepidoptera, Glyphipterigidae

\section{Zusammenfassung}

Sechs neue Arten werden beschrieben: Digitivalva kenyacola, Acrolepiopsisfalcata, Acrolepiopsis lativalvata, Acrolepiopsis juratae, Acrolepiopsis fibigeri, Acrolepia peruana. Von Acrolepiopsis jaspidata (MeYrick, 1919) wird erstmals das Weibchen beschrieben. Für vier Arten erfolgen Erstnachweise für einzelne Länder: Acrolepia dioscoreivora GIBEAux, 1989, Acrolepiopsis nagaimo YAsuda, 2000, Acrolepiopsis brevipenella MorIUti, 1972, Acrolepiopsis persimilis Moriuti, 1974. Von Acrolepiopsis halosticta (Meyrick, 1914) konnten erstmals Exemplare außerhalb der Typenserie gefunden werden. Acrolepiopsis persimilis Moriuti, 1974, bisher als Synonym von Acrolepiopsis suzukiella (MATsUMURA, 1931) betrachtet, wird als valide Art erkannt.

\section{Introduction}

Following SoHn et al. (2013) this group of genera, previously regarded as a family, is now treated as a subfamily of Glyphipterygidae.
Over several years it was possible to study material of Acrolepiinae from various zoogeographical regions. As a result, as well as some first records for several countries, six species new to science are described below. 
For the opportunity to study this interesting material I thank Don D. Davis (USNM, Washington D.C.), O. Karsholt (ZMUC, Copenhagen), B. LANDRY (MHNG, Genève), W. Mey (ZMHB, Berlin), J. DE Prins (former RMCA, Tervuren), A. Segerer (ZSM, Munich), D. STÜNING (former ZFMK, Bonn).

I thank A. D. Liston (Müncheberg) for linguistic corrections and $\mathrm{CH}$. Kutzscher (Müncheberg) for preparing the colour photographs.

\section{Abbreviations}

SDEI Senckenberg Deutsches Entomologisches Institut, Müncheberg, Germany

MHNG Museum d'historie naturelle de la Ville de Genève, Switzerland

RMCA Royal Museum for Central Africa, Tervuren, Belgium

USNM National Museum of Natural History, Washington D.C., USA

ZFMK Zoologisches Forschungsmuseum Alexander Koenig, Bonn, Germany

ZMHB Museum für Naturkunde, Leibniz-Institut für Evolutions- und Biodiversitätsforschung, Berlin, Germany

ZMUC Zoological Museum, Copenhagen, Denmark

ZSM Zoologische Staatssammlung München, Germany

\section{Systematics}

\section{Digitivalva kenyacola spec. nov.}

Holotype: $o^{\star}$, "Coll. Museum Tervuren, Kenya: Taita Hills, 26/06/1998 (I3), Mbololo Forest Edge, [leg.] U. Dall'Asta;" "RMCA ENT 000003258;" "Gen. präp. [genitalia slide] Gaedike Nr. 8029;" "Holotypus Digitivalva kenyacola sp. n. det. R. Gaedike 2014;" RMCA.

Paratype: 1 , same location, but 30/06/1998 (F3); "RMCA ENT 000003259;" “Gen. präp. [genitalia slide] Gaedike Nr. 8028;" "Paratypus Digitivalva kenyacola sp. n. det. R. Gaedike 2014;" RMCA.

Derivatio nominis: Named after the country in which the types were found.

Diagnosis (Fig. 1): Wingspan $10 \mathrm{~mm}$. Head white, scales around insertion of antennae pale grey, in the neck somewhat erected. Labial palpus oblique directed upwards, whitish, with pale scales outside on apex of the first two segments, third segment minute, pointed. Scape of antenna on underside white, on upperside pale, flagellum ringed. Thorax and tegulae white, tegulae basally with paler scales. Forewing ground-colour white with a pattern of grey and brown scales. On dorsum at $1 / 4$ a dark brown, nearly square patch, reaching to cell; at $1 / 2$ an indication of a band from costa to dorsum, first half darker brown than second half. On costa from base to $1 / 2$ some short and thin dark brown lines. Fringe with two dark brown scale-lines. The entire area more or less overlaid with pale and brown scales. Hindwing grey.

Male genitalia (Figs 7-9): Uncus short, truncated, tegumen laterally narrow, ventrally nearly triangular, with long saccus, narrower to rounded tip; valva with more or less rounded basal part, costal arm short, with rounded tip; phallus as long as vinculum + saccus, broader than saccus, nearly straight.

Female genitalia (Fig. 10): Pads of lamella postvaginalis broad, with numerous long bristles; ostium with broad, more strongly sclerotized ring, ductus bursae without stronger sclerotization, apical edge of segment VIII slightly invaginated.

Remarks: Superficially characterized by the square dark brown patch on dorsum of forewing and the two dark brown scale-lines on fringe. Male genitalia similar to D. gelida (Meyrick, 1921), but saccus narrower and longer, costal arm of valva short with rounded tip and phallus straight.

\section{Acrolepiopsis halosticta (MeYRICK, 1914)}

1 ơ $^{*}$ Malawi, Mulanje Mts, Lichenya Hut, 1840 m, Widdringtonia forest, 21.x.1996, leg. Mey \& Nuß; ZMHB: First record beside the type series, which was described from: "Nyassaland [now: Malawi], Ruo Valley.

\section{Acrolepiopsis falcata spec. nov.}

Holotype: $0^{\star}$, “TANZANIA, Tanga Region, Lushoto Distr., 1400 m, Mazumbai Forest Reserve, 30.xi.-7.xii. 1995, leg. S. Mckamey et al., coll. ZMUC, Denmark;" "Zool. Mus. Kobenhaven;" "Gen. präp. [genitalia slide] Gaedike Nr. 8026;" "Holotypus Acrolepiopsis falcata sp. n. det. R. Gaedike 2016;" ZMUC.

Derivatio nominis: Named after the sickle-shaped valvae.

Diagnosis (Figs 2a-2b): Wingspan $9 \mathrm{~mm}$. Head greybrown, above palpi somewhat lighter; labial palpus long, curved upwards, on outside grey-brown, on inside paler. Antenna with same colouration as the head; thorax and tegulae dark brown; forewing with dark brown ground colour. On dorsum before $1 / 2$ a thin yellowish stripe, reaching cell, opposite the stripe on costa a shorter stripe; the fringe around apex and basally with some minute white dots. 
Male genitalia (Figs 11-13): Vinculum with very long narrow saccus, with rounded tip; valva sickle-shaped, narrow, with pointed tip, basally somewhat broader, apodeme long; phallus a little longer than saccus + vinculum, basally rounded, apically with very minute thorns.

\section{Female genitalia: Unknown.}

Remarks: Superficially distinguishable by dark brown forewings with only minute white dots, the genitalia characterized by the sickle-shaped valvae.

\section{Acrolepiopsis lativalvata spec. nov.}

Holotype, o", "RSA, North Cape, Kamieskroon, Farm Windhoek, 16.x.2007, leg. W. Mey;" "Bachtal, ca 2 km oberh. Farmhaus [stream valley, appr. $2 \mathrm{~km}$ above farm house];" "Gen. präp. [genitalia slide] Gaedike Nr. 7529;" "Holotypus Acrolepiopsis lativalvata sp. n. det. R. Gaedike 2016;" ZMHB.

Derivatio nominis: Named after the broad apical part of the valvae.

Diagnosis (Fig. 3): Wingspan $10 \mathrm{~mm}$. Head dark grey, scales with whitish tip; labial palpus with same colouration, segments apically whitish. Scape of antenna dark grey, flagellum ringed, thorax and tegulae with same colouration as head. Forewing with dark grey scales, apically white; at $1 / 3$ on dorsum wedge-shaped white patch, characteristic for the genus, reaching the cell, white are also four thin stripes on costa between $2 / 3$ and apex, the area around the stripes overlaid with white scales. The fringe basally with some minute white dots; fringe with two dark scale-lines. One dark grey-brown patch on costa between $1 / 2$ and the first stripe, another patch on dorsum lateral of the wedge-shaped patch. Hindwing grey.

Male genitalia (Figs 14-16): Vinculum laterally narrow, ventrally triangular with a long narrow saccus with rounded tip; valva basally rounded, with long bristles, first third narrowest, the apical part broader, apically truncated with rounded angles; phallus slightly curved, basally broad rounded, narrower towards apex, as long as the entire genitalia apparatus.

\section{Female genitalia: Unknown.}

Remarks: Superficially characterized by scales with white tips and the pattern on apical third of forewing. The broad valvae distinguish the species from the other taxa in this genus.

\section{Acrolepiopsis juratae spec. nov.}

Holotype, ơ, "CONGO, DEM. REP., Bas Congo, 320 m, Nat. Res. Luki-Mayumbe, $05^{\circ} 27^{\prime} \mathrm{S}, 1^{\circ} 05^{\prime} \mathrm{E}, 29$. iii.2006, leg. J. De Prins;" "Gen. präp. [genitalia slide] Gaedike Nr. 8027;" "RMCA ENT 000003257;" "Holotypus Acrolepiopsis juratae sp. n. det. R. Gaedike 2016;” RMCA.

Derivatio nominis: Named after Jurate de Prins, who collected the specimen and enabled me the study of it.

Diagnosis (Fig. 4): Wingspan $8 \mathrm{~mm}$. Head pale greybrown, scales partly rubbed off; labial palpus curved upwards, on outside grey brown, on inside and apically on each segment paler. Scape of antenna also grey-brown, on upper side paler, flagellum ringed; thorax and tegulae basally grey-brown, apically paler. Forewing dark brown, mixed with lighter brown, the lighter brown parts mainly on costal part as some short stripes. Dark brown are a more or less square patch on costa after $1 / 2$ and as a prolongation another patch on cell, and the area around apex. On dorsum at $1 / 2$ a white, wedge-shaped patch. Hindwing grey.

Male genitalia (Figs 17-18): Uncus long, anellus with $\mathrm{V}$-shaped incision, vinculum with saccus as long as valva, saccus with broad rounded apex; valvae straight, laterally minutely dentate, with small hook-shaped tip, dorsal parts nearly connected; phallus somewhat longer than valva, broadly rounded basally, vesica with minute thorns.

Female genitalia: Unknown.

Remarks: Superficially without clearly distinctive characters; the straight valvae of the genitalia with their minute, hook-shaped tips are characteristic.

\section{Acrolepiopsis jaspidata (MEYRICK, 1919)}

My collegue Bernard Landry enabled me to study some specimens of this species, collected on the Galapagos Islands (see: RoQUE-Álbelo \& LANDRY, 2006; 2015).

1 , ECU: Galapagos, Santa Cruz agriculture zone, near (NNW) Bella Vista, 223 m, S 00,41.297', W 90,19.670', 7.iv.2004, leg. B. Landry; MHNG; 3 đ`, 2 + , ECU: Galapagos, Santa Cruz, NNW Bella Vista, 225 m, S 00,41.293', W $90^{\circ}, 19.665^{\prime}, \quad$ 18.ii.2005, leg. B. Landry; MHNG; SDEI. The series contains females, which were hitherto unknown, and it is thus possible to describe the genitalia structure for the first time (Fig. 19).

Pads of lamella postvaginalis narrow, bristled; Ostium and nearly the entire ductus bursae funnel-shaped, more strongly sclerotized, in corpus bursae numerous rows of small, stronger sclerotized thorns.

The species was hitherto known only from Peru (type series). 


\section{Acrolepiopsis persimilis Moriuti, 1974, stat. rev.}

The study of a small series from Taiwan shows that the taxon persimilis, described by Moriuti in 1974, is not a synonym of Acrolepiopsis suzukiella (MATsumura, 1931), as was published earlier (GAEDIKE, 1979). There are clear differences in the genitalia structure, especially the size of the small preapical tooth on valva.

Hitherto known only from the locality where the type series was collected (Japan, Honshyu, Mt. Takaosan). Recorded now for the first time from Taiwan:

$20^{\star}, 1$ ㅇ, Taiwan: Nan Tow Co., Tayuling, 2500 m, June 9-18 1980, forest, leg. D. R. Davis;" USNM; SDEI; $20^{*}$, 1 ㅇ, Taiwan, Nantou, Meifeng, Rei-Yan-shi, 29.x.-3.xi. 1998, leg. Mey \& Ebert;" ZMHB; SDEI.

\section{Acrolepiopsis nagaimo YASUDA, 2000}

The examination of some undetermined specimens from Nepal shows that nagaimo, described from Japan, has been found for the first time in Nepal. Perhaps it was introduced with the host plant Dioscorea opposita.

Examined material: $1 \sigma^{*}$, Nepal, Kathmandu - Chauni, 1400 m, 27.v.1967, leg. Dierl - Forster - Schacht; ZSM; $1 \sigma^{*}$, Nepal, Kathmandu Valley, Godavari, 1600-1800 m, 5.-7.viii.1967, leg. Dierl - Forster - Schacht; ZSM; 1 o $^{*}$, Nepal, Centr., N, Mailung Khota, 1050 m, 24.x.1995, leg. M. Fibiger; ZMUC.

\section{Acrolepiopsis fibigeri spec. nov.}

Holotype: ${ }^{\star}$, "Nepal, Centr. N, Ganesh Himal, Ndesim, 2200 m, 23.x.1995, leg. M. Fibiger;" "Zool. Mus. Kopenhavn;" "Gen. präp. [genitalia slide] Gaedike Nr. 8064;" "Holotypus ơ, Acrolepiopsis fibigeri sp. n., det. R. Gaedike, 2016;" ZMUC.

Derivatio nominis: Named in honour of Michael Fibiger, the well-known specialist of Noctuidae, who has also collected numerous new and poorly known Microlepidoptera.

Diagnosis (Fig. 5): Wingspan $9 \mathrm{~mm}$. Head light greybrown. Labial palpus curved upwards, scales on outside brown mixed with light brown, on inside paler, tip of last segment brown. Scape of antenna brown, flagellum ringed. Thorax and tegulae dark brown mixed with light brown. Forewing ground-colour brown with a light brown, blackish and white pattern. White are: on dorsum at $1 / 3$ a wedge-shaped patch, on costa at apical third three thin stripes and on the entire apical third some minute white dots. On costa at $2 / 3$ an almost blackish patch, obliquely directed to apex, another blackish dot before apex; the entire costa covered with light brown and dark brown short stripes. Hindwing light grey.
Male genitalia (Figs 20-22): Vinculum narrow, saccus very long and thin, with rounded tip; valva basally rounded, parallel-sided to apex, ventral edge of apex with small prolongation, the shape differs depending on preparation; phallus somewhat longer than the entire genital, slightly curved, basally rounded.

\section{Female genitalia: Unknown.}

Remarks: Superficially similar to some of the other species from Nepal and Japan, but the genitalia structure (shape of valvae) make the new species clearly distinguishable.

\section{Acrolepiopsis brevipenella MoRIUTI, 1972}

In the collection H. Höne (ZFMK) was found $1 \sigma^{\text {t }}$ from China: Prov. North-Yuennan, Li-kiang. This is the first record for the country. Hitherto known from Japan and Mongolia.

\section{Acrolepia peruana spec. nov.}

Holotype đ`, "PERU, Dept. Huánaco 15: $25 \mathrm{~km} \mathrm{NE}$ Huánaco, Cordillera Carpish, Pattytrail 2600 m, 8.10.ii.1987, O. Karsholt leg., Zool. Mus. Copenhagen;" "Gen. präp. [genitalia slide] Gaedike Nr. 3787;" "Holotypus ơ Acrolepia peruana sp. n. det. R. Gaedike 2016;" ZMUC.

Derivatio nominis: Named after the country in which the type was collected.

Diagnosis (Fig. 6): Wingspan $13 \mathrm{~mm}$. Head basally, from neck to insertion of antennae, creamy, apically white; labial palpus long, curved upwards, on outside brown, segments apically lighter, on inside light creamy. Scape of antenna brown, on upper side light creamy, flagellum ringed; thorax and tegulae basally brown, apically light creamy. Forewing dark brown, mixed with light brown, without clear pattern, only on costa some short light brown stripes. On dorsum two white patches: at 1/3 a large wedge-shaped patch, a smaller square patch after $1 / 2$; apex pale, almost white; the last fourth of forewing with some minute white dots. Hindwing light grey.

Male genitalia (Fig. 23): Anellus band-shaped, vinculum laterally broadly band-shaped, ventrally triangular, saccus stout, with rounded tip; valva with bristled, rounded basal part and slightly curved dorsal arm, tip rounded, with numerous strongly sclerotized pointed thorns; phallus as long as entire genital, slightly curved, basally rounded.

Female genitalia: Unknown. 
Remarks: Superficially characterized by the two white patches on dorsum of forewing, and in the genitalia characterized by valvae with the strongly sclerotized apical thorns.

\section{Acrolepia dioscoreivora GIBEAUX, 1989}

$1 o^{*}$, Malawi, Zomba Plateau, $1230 \mathrm{~m}$, rain forest, 19.x. 1996, leg. Mey \& Nuß; ZMHB.

First record from the African continent, the species was hitherto known only from the holotype location in Madagascar.

\section{References}

GaEdike, R. 1979: Nomenklatorische Bemerkungen zu paläarktischen Acrolepiiden (Lepidoptera). - Beiträge zur Entomologie 29 (2): 413-414.

Gibeaux, CH. 1989: Note homonymique dans le genre Acrolepia Curtis. (Lep. Yponomeutidae). - Nouvelle Revue d'Entomologie (N.S.) 6 (1): 36.

Matsumura, S. 1931: 6000 Illustrated Insects of JapanEmpire. - Tokyo: 1-1719.

Meyrick, E. 1914(xii): Exotic Microlepidoptera. London, TAYLOR and FRANCIS 1 (9): 257-288.

Meyrick, E. 1919(viii): Exotic Microlepidoptera. London, TAYLOR and Francis 2 (8): 225-256.

Moriuti, S. 1972: Seven new species of Acrolepiidae from Japan and Formosa (Lepidoptera). - Kontyû 40 (4): 243-254, 20 figs.
Moriuti, S. 1974: A new Japanese Acrolepiid (Lepidoptera). - Tyô To Ga (Transactions of the Lepidopterological Society of Japan) 25 (4): 111-112, 8 figs.

Roque-Álbelo, L. \& LANDrY, B. 2006: Lista annotada de los Lepidópteros de las islas Galápagos, Ecuador. - Charles Darwin Research Station, Puerto Ayora, Ecuador: 1-32.

Roque-Álbelo, L. \& LANDry, B. 2015: CDF Checklist of Galapagos Butterflies and Moths - FCD Lista de especies de Mariposas y polillas de Galápagos. - In: Bungartz, F.; Herrera, H.; Jaramillo, P.; Tirado, N.; Jiménez-Uzcátegui, G.; Ruiz, D.; Guézou, A. \& Ziemmeck, F. (eds.): Charles Darwin Foundation Galapagos Species Checklist - Lista de Especies de Galápagos de la Fundación Charles Darwin. Charles Darwin Foundation/Fundación Charles Darwin, Puerto Ayora,Galapagos.

[available online under: http://www.darwinfoundation. org/datazone/checklists/terrestrial-invertebrates/ lepidoptera/ last updated 30 Nov. 2015.].

Sohn, Jae-Cheon; Regier, J. C.; Mitter, C.; Davis, D. D.; LANDrY, J.-F.; Zwick, A. \& Cummings, M. P. 2013: A Molecular Phylogeny for Yponomeutoidea (Insecta, Lepidoptera, Ditrysia) and Its Implications for Classification, Biogeography and the Evolution of Host Plant Use. - PLoS ONE 8 (1): 1-23, 7 figs.

YAsUdA, K. 2000: A new species of the genus Acrolepiopsis GAEDIKE (Lepidoptera: Acrolepiidae) injurious to Chinese yam and its closely allied species from Japan. - Applied Entomology and Zoology 35 (4): 419-425, 13 figs. 

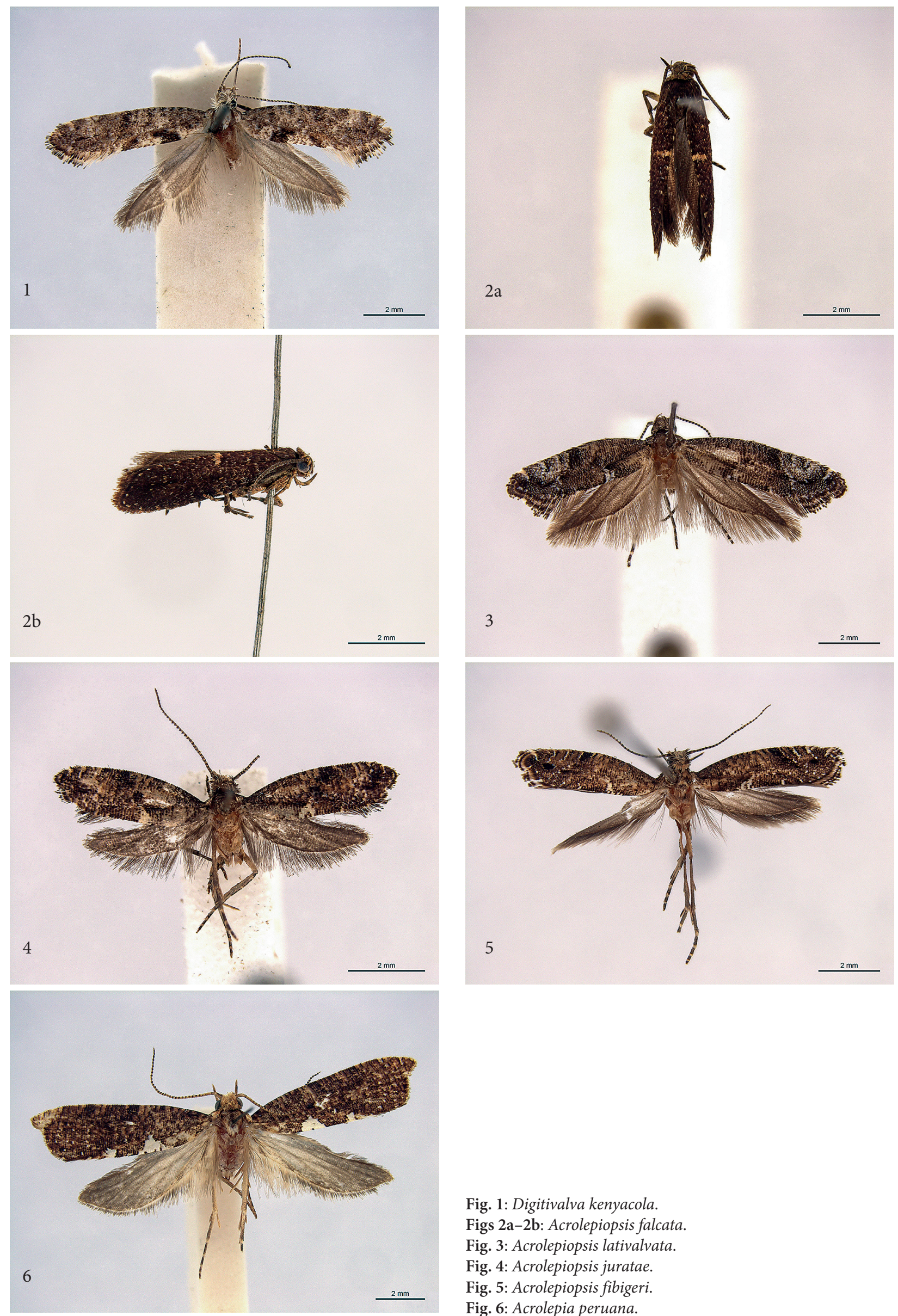

Fig. 1: Digitivalva kenyacola.

Figs 2a-2b: Acrolepiopsis falcata.

Fig. 3: Acrolepiopsis lativalvata.

Fig. 4: Acrolepiopsis juratae.

Fig. 5: Acrolepiopsis fibigeri.

Fig. 6: Acrolepia peruana. 

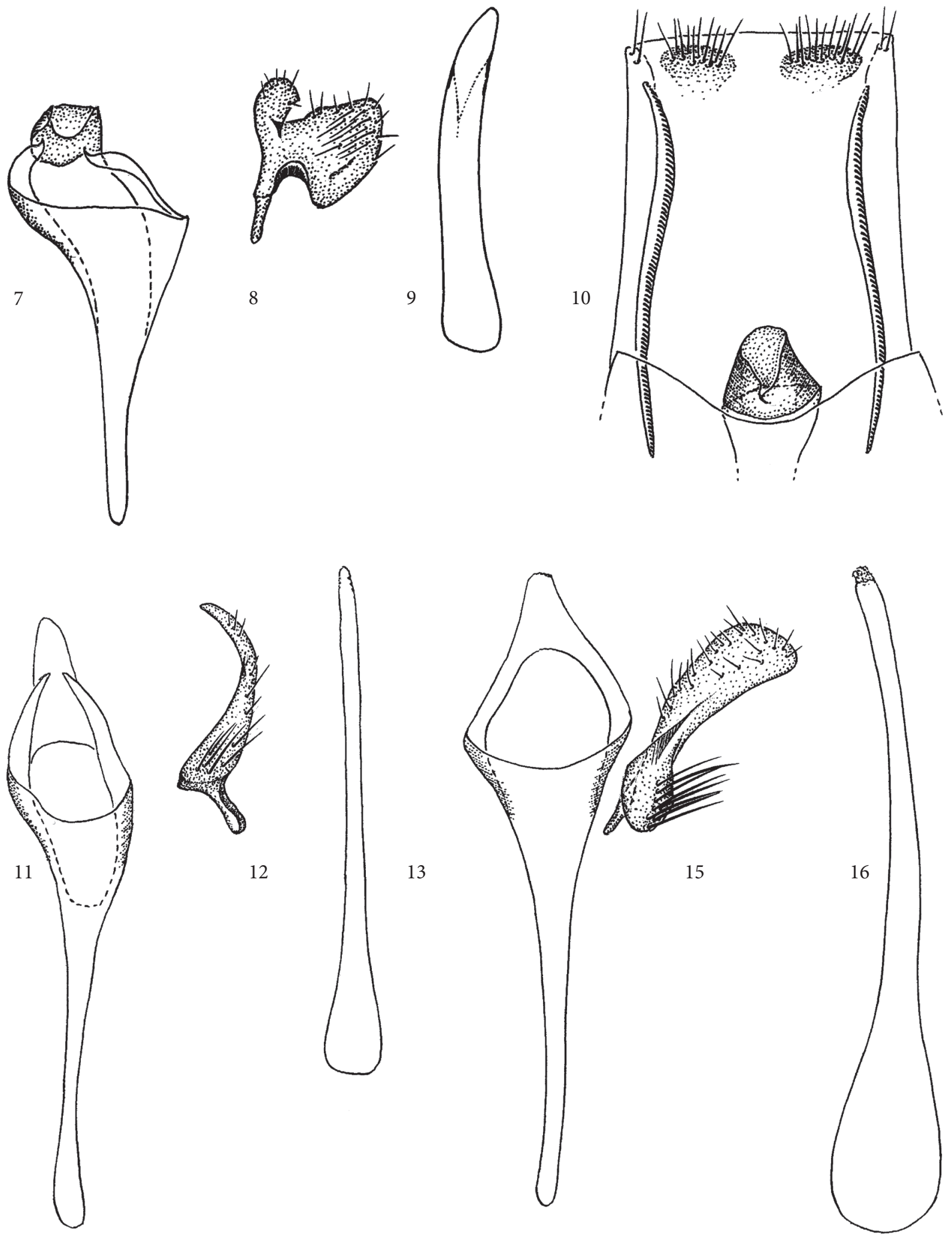

Figs 7-16: Digitivalva kenyacola (male: 7 - uncus-tegumen-vinculum-saccus; 8 - valva; 9 - phallus; 10 - female), Acrolepiopsis falcata (male: 11 - uncus-tegumen-vinculum-saccus; 12 - valva; 13 - phallus), Acrolepiopsis lativalvata (male: 14 - uncus-tegumenvinculum-saccus; 15 - valva; 16 - phallus). 

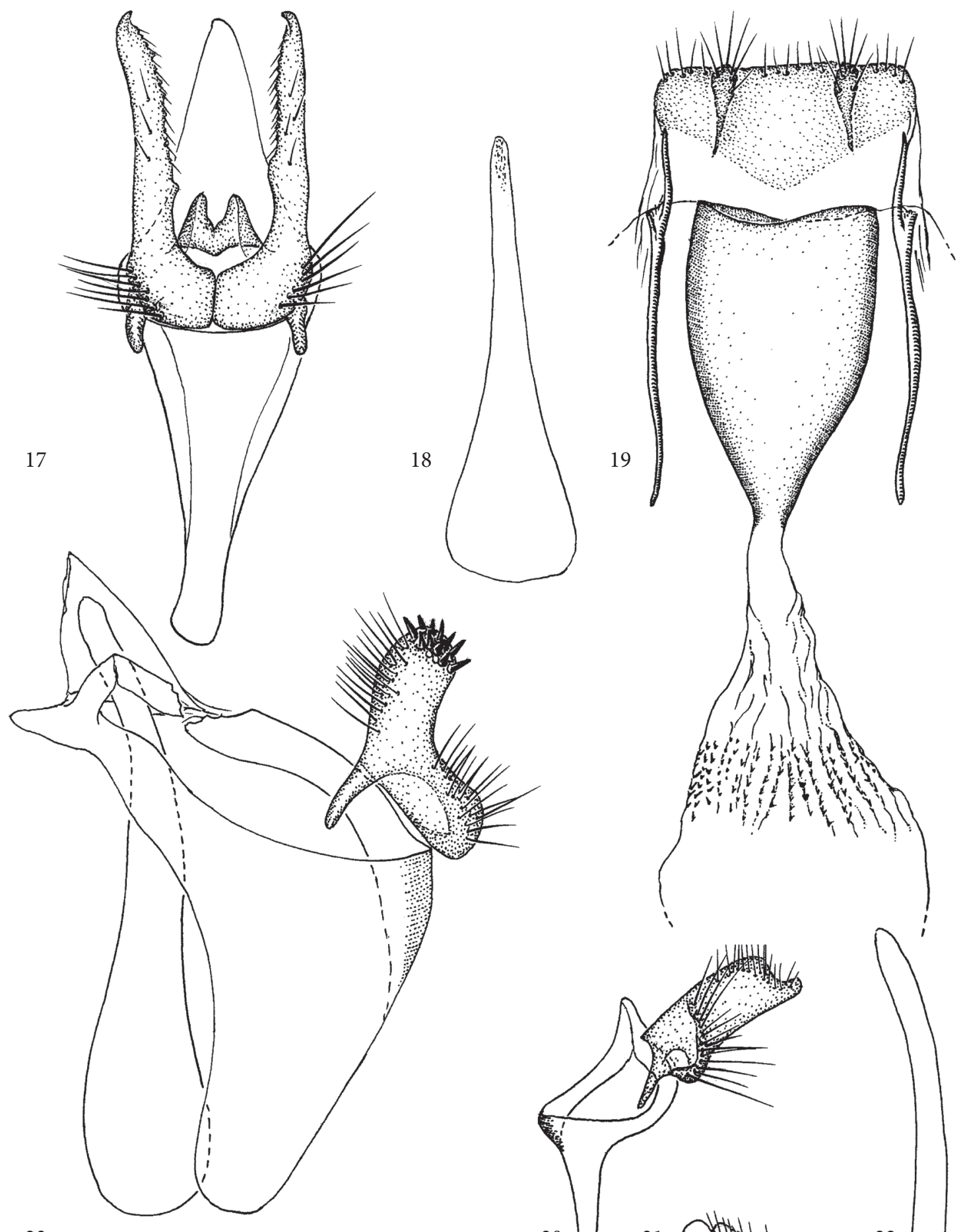

Figs 17-23: Acrolepiopsis juratae (male: 17 - uncus-tegumen-vinculum-saccus, valvae; 18 - phallus), Acrolepiopsis jaspidata (female: 19), Acrolepiopsis fibigeri (male: 20 genital apparatus, one valva and phallus removed; 21 - left valva; 22 - phallus), Acrolepia peruana (male 23: left valva removed).

1
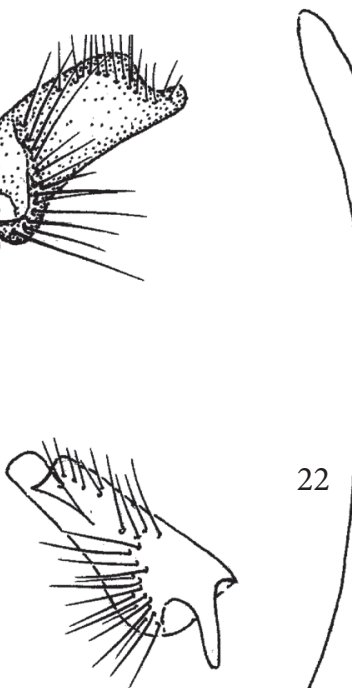

22

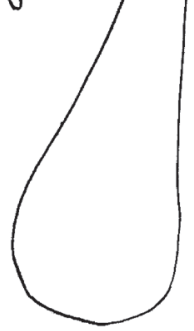

